\title{
Development of instant gluten free porridge
}

\author{
Dipali Saxena $^{1 *}$, Shailja Jain ${ }^{2}$ and Aishwarya Dixit ${ }^{1}$ \\ ${ }^{1}$ Centre for Food Technology, Jiwaji University, Gwalior M.P., India \\ ${ }^{2}$ Department of Food and Nutrition, Home Science, K.R.G. P.G. College, Gwalior M.P., India
}

\begin{abstract}
Appropriate nutrition practice plays a vital role in determining optimal health and development. The main aim of this study was to develop healthy nutritious malted breakfast especially for celiac and autism patients. The raw materials were procured from the Rajmata Vijayaraje Scindia Krishi Vishwavidhalaya. The malted grains (ragi, sorghum and mung) were mixed in different proportion to prepared salty Porridge and named as treatments T1, T2 and T3. Organoleptic analysis was done to assess the sensory attributes by using nine point of hedonic scale. The result shows that T3 scored best in overall acceptability among all the treatments. Hence, it was concluded that germinated grains can be suitably used as porridge.
\end{abstract}

\section{Introduction}

The current scenario of nutritional status in the country is distributing, necessitating essential remedial measures. In recent years, a wide range of processed foods in ready-to-eat form have been marketed with increased interests in health foods. In India, wide ranges of traditional foods are consumed as breakfast. To attract consumers, traditional products must be reformulated to meet demands for fast preparation time, convenience and health significance. Wheat porridge (dalia) is a major breakfast cereal in north India. In addition to whole grain benefits, multigrain concept can provide breakfast foods with number of benefits associated with these grains. The cooking of grains with steam under pressure is the initial process for porridge making. This process is important as it develops the grain properties necessary for the development of product characteristics such as flavour, colour and texture- primarily by gelatinisation of starchy grain fractions. This multigrain blends helps to mix different whole grains to maximize their nutritional, functional and sensory properties

\section{Autism and celiac disease}

Intensified opioid activity would result causing the abnormalities of perception, cognition, emotions and behaviours that are observed in autism. This theory is often called the "the Opioid-Excess Theory" given by Panksepp [1]. These peptides react with opiate receptors in the brain, thus mimicking the effects of opiate drugs like heroin and morphine. The peptide from wheat is called gluteomorphin (gluten+morphine) and the peptide from milk is called caseomorphin (casein+morphine). According Sciarini et al. [2] gluten must be eliminated from the diet of patients suffering from celiac disease because its ingestion causes serious intestinal damage.

\section{Ragi}

Finger millet is commonly known as Ragi (Eleusine coracana) which is having family Gramineae. Finger millet is a cereal crop and is mostly preferred as staple food by the peoples from the arid and semi arid region. Importance of finger millet has been increased due to its dietary fibre, starch pattern and high calcium-iron contents. In addition, it is nutritionally superior to Wheat and Rice because of its high Calcium (380 mg), Dietary fibre (18 g) and Phenolic compounds (0.03 g-3 g) per
$100 \mathrm{~g}$. The health benefits from ragi consumption are attributed to its polyphenol and dietary fibre contents. Its health beneficial effects are anti-diabetic, anti-tumorigenic, atherosclerogenic effects, antioxidants, etc. There are three anti-nutritional factors are present in the ragi viz., phytic acid, tannin and trypsin inhibitor. The process of malting improves digestibility, sensory and nutritional quality of finger millet and lowers anti-nutritional factors from it [2-10].

\section{Mung}

Mung bean (Vigna radiata L.; Family: Fabaceae) is well known as green gram or moong bean. Mung beans are recognized for its high nutritive value, composed of about $20 \%-25 \%$ protein of total dry weight. Among them, globulin (60\%) and albumin (25\%) are the primary storage proteins. The protein in the mung beans contains a greater quantity of essential amino acids, including phenylalanine, leucine, isoleucine, valine, tryptophan, arginine, methionine, and lysine For incidence during sprouting, the reduces the content of triacylglycerol, increases the levels of free amino acids and total phenolic acids and alters the metabolites of fatty acid methyl esters, free fatty acids, monosaccharides, and disaccharides. Furthermore, these sprouts contain more potential antioxidant substances such as polyphenols when compared to the raw seeds. Hence, germination is thought to enhance the nutritional and medicinal qualities of mung beans [11-15].

\section{Sorghum}

Sorghum is a genus of flowering plants in the grass family Poaceae. Seventeen of the 25 species are native to Australia, They found that grain sorghum protein varies from 4.4 to $21.1 \%$ with a mean value of $11.4 \%$. Sorghum grain is known for its hardness compared to other food grains. The hardness of the grain is due to higher content of

${ }^{*}$ Correspondence to: Dipali Saxena, Centre for Food Technology, Jiwaji University, Gwalior M.P., India, E- mail: dipali.ju.ft@gmail.com

Key words: nutrition, vital, porridge, grains

Received: February 07, 2019; Accepted: March 01, 2019; Published: March 04 2019 
protein prolamin. Prolamin content varies from 3.6 to $5.1 \%$. The Lysine content ranges from 1.06 to $3.64 \%$. The protein fractionation studies in sorghum indicated that the distribution of albumin-globulin, prolamin and glutelin is about 15,26 and $44 \%$ respectively of total nitrogen. The important nutritional implication of phytic acid is that it chelates di and trivalent cations particularly $\mathrm{Fe}, \mathrm{Ca}, \mathrm{Na}, \mathrm{Mg}$ and $\mathrm{Zn}$ and decreases their bioavailability. Phytic acid forms insoluble compounds with mineral elements including $\mathrm{Ca}, \mathrm{Fe}, \mathrm{Mg}$ and $\mathrm{S}$. Fermentation resulted in a mean decrease of phytic acid of $64.8 \%$ after 96 hours and $39.0 \%$ after 72 hours in sorghum grain. Malting also resulted in a mean decrease of 23.9 and $45.3 \%$ after 72 and 96 hours, respectively. Phytic acid occurs primarily in the seed coats (brain) and germ of plant seeds. Genetic variation for low phytic acid is available in rice mutants. Presently the new research investigations on polyphenols and phytic acid consider these compounds as health factors and consumption of these factors increases immunity in animal and human systems against several diseases.

The present study was carried out to develop multi grain Instant porridge having greater nutritional value with reference to celiac and autism patients. The aim of the present work was to prepare gluten free Porridge as breakfast cereal using germinating grains and to find out the acceptance of porridge.

\section{Materials and methods}

The details of materials, procedures followed have been elaborated under the following heads:

1. Procurement of raw materials: Mung, sorghum ragi and other cereals were brought from the Rajmata Vijayaraje Scindia Krishi Vishwavidhalaya and other spices from local market of Gwalior

2. Sprouting of cereals: Table 1 and Figure 1.

3. Dehydration of sprouts: Table 2 and Figure 2.

4. Sprouted cereals: Figure 3.

\section{Treatment and replication of developed products}

Table 3.

\section{Formation of porridge}

Dry mixing of all ingredients with salt, oils and some dry seasonings and packaged in Poly ethylene pack. This porridge requires pressure cooking of 4 whistles to form a final porridge like consistency [16-20].

Table 1. Standards of sprouting cereals

\begin{tabular}{|c|c|c|c|}
\hline Cereal & Time & Temp & Length (avg) \\
\hline Finger millet (ragi) & 24 hrs. & $27^{\circ} \pm 3^{\circ} \mathrm{C}$ & $1.5 \mathrm{~cm}$ \\
\hline Vigna radiate (mung) & 3 days & $25^{\circ} \mathrm{C}$ & $4 \mathrm{~cm}$ \\
\hline Sorghum & 3 days & $27^{\circ} \pm 2^{\circ} \mathrm{C}$ & $1.2 \mathrm{~cm}$ \\
\hline
\end{tabular}

Table 2. Standards of dehydration of grains

\begin{tabular}{|l|c|c|c|}
\hline Cereal & Time & Temp & Place \\
\hline Finger millet (ragi) & 2 days & $25^{\circ} \mathrm{C}$ & Shade \\
\hline Vigna radiate (mung) & $20 \mathrm{hrs}$ & $50^{\circ} \mathrm{C}$ & Hot air oven \\
\hline Sorghum & $24 \mathrm{hrs}$ & $40^{\circ} \mathrm{C}$ & Hot air oven \\
\hline
\end{tabular}

Table 3. Proportions of dry cereals and pulse in porridge

\begin{tabular}{|c|c|c|c|c|c|}
\hline Treatment & Ragi & Sorghum & Brown rice & Mung & Rajma \\
\hline T1 & 40 & 40 & & 20 & \\
\hline T2 & 20 & 30 & 10 & 20 & 20 \\
\hline T3 & 20 & 40 & 10 & 20 & 10 \\
\hline
\end{tabular}

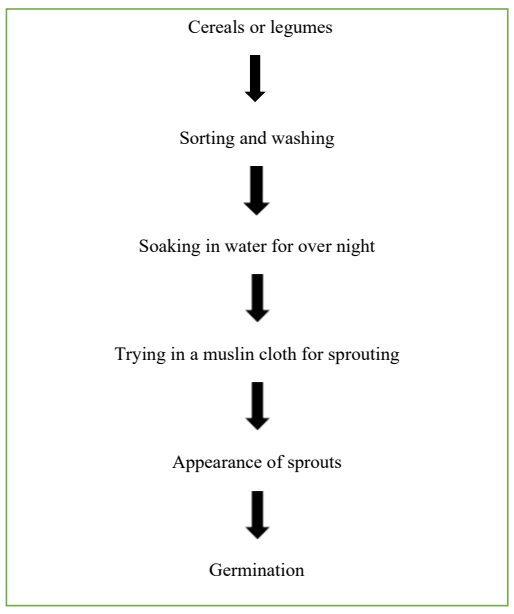

Figure 1. General procedure of sprouting cereals

Source: Khader Vijaya, Textbook of Food Science and Technology, published by directorate of information and publication of agriculture ICAR.
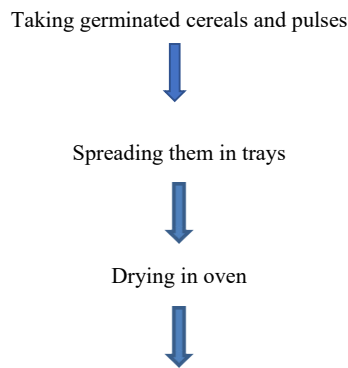

Repeating the process till moisture disappear

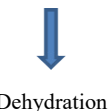

Figure 2. General protocol of dehydration of sprouts Source: Shipra Srivastava et al. Int J Pure App Biosci 3(1): 171-185.
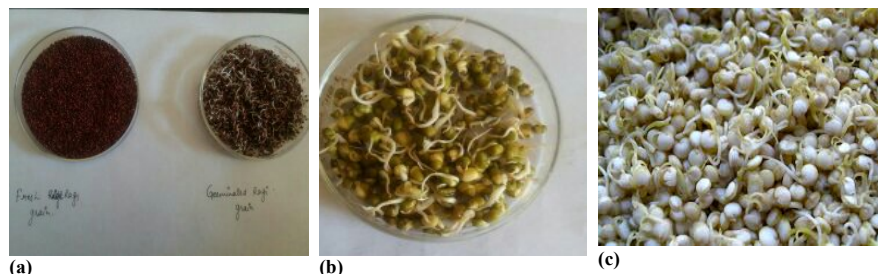

Figure 3. Pictures of sprouting (a)Ragi (b)Mung (c)Sorghum

\section{Organoleptic analysis}

Cooked multigrain porridge was served hot and evaluated for sensory attributes (appearance, colour, texture, stickiness, flavor and taste) were placed near the twenty panelists to evaluate for acceptability at nine point hedonic test. The panelist judged the acceptability and measured the pleasurable and unpleasable experience' $s$ of the food products ranging from 'like extremely' to 'dislike extremely' [21]. Sensory evaluation of the developed product was evaluated by 20 semi trained panel from Centre for food technology Jiwaji University Gwalior. The sensory attributes of color, appearance, texture, flavor, taste and overall acceptability by using nine point hedonic scale score card. The samples were placed before the lactating mother with sample code T1, T2, T3. 


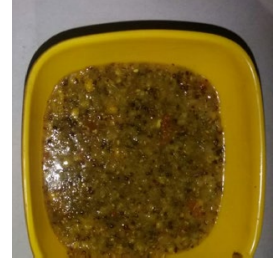

(a) $\mathrm{T} 1$

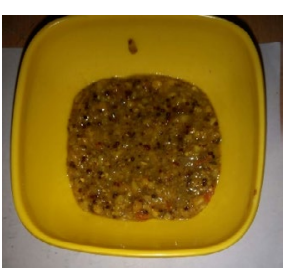

(b) $\mathrm{T} 2$

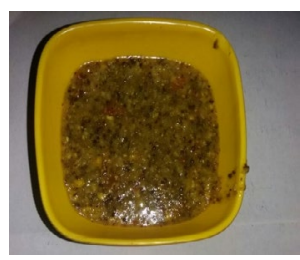

(c) T3
Figure 4. Cooked porridge of different treatments

Table 4. Sensory analysis results

\begin{tabular}{|c|c|c|c|c|c|}
\hline Treatment & Color & Flavor & Taste & Aftertaste & $\begin{array}{c}\text { Over all } \\
\text { acceptability }\end{array}$ \\
\hline T1 & 6.7 & 7.1 & 7.4 & 7.0 & 7.05 \\
\hline T2 & 7.2 & 7.7 & 7.2 & 7.5 & 7.40 \\
\hline T3 & 8.2 & 8.6 & 8.1 & 8.2 & 8.27 \\
\hline
\end{tabular}

\section{Result and discussion}

Figure 4 and Table 4.

The data collected showed that treatment $\mathrm{T} 3$ were the beat treatment on sensory analysis as it contains equate proportions of cereals and legumes.

\section{Conclusion}

The sensory parameter of mouth feel was more correlated with degree of cooking of instant multigrain porridge, thus influencing overall acceptability score for multigrain porridge treated under different processing conditions.

\section{Acknowledgement}

We were grateful to department, Department of Home Science (Foods and Nutrition) K.R.G P.G Autonomous College, Gwalior M.P. and Prof. G.B.K.S Prasad, Coordinator of Centre for Food Technology, Jiwaji University, Gwalior for all the facilities and opportunities that we had been provided. I also thankful to my guides Prof. Shailja Jain, Prof. Neeraj Jain, Dr. Mukesh Chunglani and Dr. Richa Changulani for their constant support and encouragement that they have provided throughout the work.

\section{References}

1. Panksepp J (1969) A neurochemical theory of autism, T/NS_July 1969.

2. Sciarini SL, Ribotta DP, León EA, Pérez TG (2008) Influence of gluten-free flours and their mixtures on batter properties and bread quality. Food and Bioprocess Technology.
3. Kavas A, Sedef N (1991) Nutritive value of germinated mung beans and lentils. $J$ Consum Stud Home Econ 15: 357-366.

4. Anderson RA, Conway HF, Pfeifer VF, Griffin EL (1969) Roll and extrusion cooking of grain sorghum grits. Cereal Sci Today.

5. Caldwell EF, Fast RB, Ievolella J, Lauhoff C, Levise H, et al. (2000) Cooking of ready to eat fast food cereals. Cereal Foods World 45: 244-252.

6. Tang D, Dong Y, Ren H, Li L, He C (2014) A review of phytochemistry, metabolite changes, and medicinal uses of the common food mung bean and its sprouts (Vigna radiata). Chem Cent J 8: 4.

7. Engels C, Hendrick M, Tobback P (1987) Limited multiplayer desorption of brown, parboiled rice. Int J Food Sci Technol 1987: 219-223.

8. Hendrick M, Engels C, Tobback P (1987) Three dimensional TLM models for water diffusion in white rice. J Food Eng 6: 187-192.

9. Hsu KH, Kim CJ, Wilson LA (1983) Factors affecting water uptake of soyabeans during soaking. Cereal Chem 60: 208.

10. Hulse JH, Liang EM, Pearson OE (1980) Sorghum and the millets: Their composition and nutritional value. London, Academic Press.

11. Jambunathan R, Mertz ET (1973) Relationship between tannin levels, rat growth, and distribution of proteins in sorghum. J Agric Food Chem 21: 692-696. [Crossref]

12. Jones D, Chennaswamy R, Tan Y, Hanna M (2000) Physicochemical properties of ready-to-eat breakfast cereals. Cereal Foods World 40: 164-168

13. Jom KN, Frank T, Engel KH (2010) A metabolite profiling approach to follow the sprouting process of mung beans (Vigna radiata). Metabolomics 7: 102-117.

14. Kim SI, Andaya CB, Newman JW, Goyal SS, Tai TH (2008) Isolation and characterization of a low phytic acid rice mutant reveals a mutation in the rice orthologue of maize MIK. Theor Appl Genet 117: 1291-1301. [Crossref]

15. Makokha AO, Oniang'o RK, Njoroge SM, Kamar OK (2002) Effect of traditional fermentation and malting on phytic acid and mineral availability from sorghum (Sorghum bicolor) and finger millet (Eleusinecoracana) grain varieties grown in Kenya. Food Nutr Bull 23: 241-245.

16. Rane AG, Vora JD, Priyanka J (2014) A review of the biochemical, antimicrobial and organoleptic studies on the germination profile of finger millet (Eleusine coracana). Int J Food Sci Nutr Diet 3: 129-133.

17. Kudre TG, Benjakul S, Kishimura H (2013) Comparative study on chemical compositions and properties of protein isolates from mung bean black bean, and Bambara groundnut. J Sci Food Agric 93: 2429-2436.

18. Thapliyal V, Singh K (2015) Finger millet: Potential millet for food security and power house of nutrients. International Journal of Research in Agriculture and Forestry 2: $22-33$.

19. Huang X, Cai W, Xu B (2014) Kinetic changes of nutrients and antioxidant capacities of germinated soybean (Glycine max L.) and mung bean (Vigna radiata L.) with germination time. Food Chem 143: 268-276.

20. Zubairuddin SM, Sonkar C, Masih D, Sonkar N (2015) Development and quality evaluation of ragi fortified cake. The Allahabad Farmer 70: 23-26.

21. Avantina S (2006) Textbook of food science and technology

Copyright: (C2019 Saxena D. This is an open-access article distributed under the terms of the Creative Commons Attribution License, which permits unrestricted use, distribution, and reproduction in any medium, provided the original author and source are credited. 